Universidad de Lima

Facultad de Ingeniería y Arquitectura

Carrera de Ingeniería Industrial

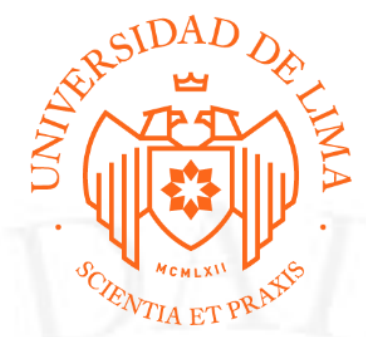

\title{
MEJORA INTEGRAL EN LA EMPRESA AUTOREL SRL.
}

Trabajo de investigación para optar el Título Profesional de Ingeniero Industrial

\author{
Alessandra Dongo de Villena \\ Código 20110405 \\ Mauricio Mathey García-Rada \\ Código 20110748
}

\author{
Asesor \\ Gerardo Ferrer Aspillaga
}

Lima - Perú

Abril de 2020 